\title{
Analyzing the Students' Conceptual Change on Kinetic Theory of Gases as a Learning Effect though Computer Simulations-Assisted Conceptual Change Model
}

\author{
Achmad Samsudin ${ }^{1, *}$, Nurul Azizah ${ }^{1}$, Dedi Sasmita ${ }^{1}$, Rasmitadila $^{2}$, Mukhammad Aji Fatkhurrohman $^{3}$, \\ Supriyatman ${ }^{4}$, Firmanul Catur Wibowo ${ }^{5}$ \\ ${ }^{1}$ Department of Physics Education, Universitas Pendidikan Indonesia, Bandung, Indonesia \\ ${ }^{2}$ Department of Elementary Education, Universitas Djuanda, Bogor, Indonesia \\ ${ }^{3}$ Department of Science Education, Universitas Pancasakti Tegal, Tegal, Indonesia \\ ${ }^{4}$ Department of Physics Education, Universitas Tadulako, Palu, Indonesia \\ ${ }^{5}$ Department of Physics Education, Universitas Negeri Jakarta, Jakarta, Indonesia
}

Received November 10, 2019; Revised December 23, 2019; Accepted December 25, 2019

Copyright $\subseteq 2020$ by authors, all rights reserved. Authors agree that this article remains permanently open access under the terms of the Creative Commons Attribution License 4.0 International License

\begin{abstract}
This study is to analyze the students' conceptual change on the kinetic theory of gases afterward learning with a computer simulation-assisted conceptual change model. CS-CCM consists of six phases; 1) commit to a position 2) expose beliefs 3) confront belief 4) accommodate the concept 5) extend the concept 6) go beyond. CS-CCM was conducted to 27 students (average age of 17 years old) who came from one of high school in Belitung. The research method was pre-experimental design with a one-group pretest-posttest design. The instrument used a four-tiers test-kinetic theory of gases (FT-KTG) consisting of 11 questions and the results of the test categorized into five categories of students' conceptions, consisting of; sound understanding (SU), partial understanding (PU), misconception (MC), no understanding (NU), and not being encoded (UC). Students' conceptual change is based on students' pre-test and post-test conception profiles. There are six types of changes in students conceptions; reinterpretation (Ri), revision (Rv), construction (Co), disorientation (Di), scientific conception from the beginning (Sc), and static (St). The results show that $86 \%$ of students whose conceptual change are in the "satisfying category" and CS-CCM is effective can be used as a learning model to change students' conceptual.
\end{abstract}

Keywords Conceptual Change, Kinetic Theory of Gases, Computer Simulations-Assisted Conceptual Change Model

\section{Introduction}

Conceptual change is all processes that are used to correct or remove naive concepts [1]. Naive conception is divided into two, namely: the knowledge that is easily revised or deleted through instructions called preconceptions and knowledge that is very resistant to change remains strong when faced with instructions called misconceptions [1]. Naive conceptions must be revised to increase students' understanding of a concept.

White [2] states that concepts are related to classification, understanding the meaning of a concept can be known when there are things that can be properly classified as belonging to the concept. This relates to the ability to specify different contexts. On the other hand, conception relates to all the knowledge possessed by an individual and is associated with the name of the concept. Conception is formed by the concept system [1, 2].

There are several concepts from various ontological categories that are categorized by scientists [1]. Based on the term, ontology is defined as "the science of existence", the science of discussing the existence of something that is critically critical [3]. Changes in conception must involve changes in ontological categories in students' cognitive structures. Changes in the ontological category are concepts that were initially categorized incorrectly by students after being given a treatment that was re-categorized by students according to the categories of scientists. For the attainment of ontological change, the learning process involved in changing students' conceptions is needed, as well as providing a framework for designing instructions that facilitate expected changes 
[4]. Three main ontological categories are material, process, and mental state [3].

Rusanen \& Lappi [5] states that there are three main types of conceptual changes, namely revision, reinterpretation, and discovery. Revision is a conceptual change by improving pre-existing conceptions. Reinterpretation is a conceptual change in students, which implies that students provide new interpretations in a domain. Discovery is a conceptual change in the form of construction or construction of a new set of concepts.

In this study, students' conception change if the understanding of students' conceptions changes from one level of understanding to another. There are five levels of students' conceptions, namely understanding concepts, understanding partial concepts, misconceptions, not understanding concepts [6]. In this study, the expected conceptual changes are conceptions students who change from misconception, do not understand concepts and conceptions that cannot be coded to understand concepts or understand some concepts.

One of the concepts of physics that is less understood by students and has a naive conception is the kinetic theory of gas. Kinetic theory of gases is a material that is quite important because this material is used to understand another science concept, namely thermodynamics. Lack of understanding of students' concepts in the kinetic theory of gas material stated by: Nurhuda, Rusdiana, \& Setiawan [7] found that only $33 \%$ of 32 students really understood the ideal gas law sub-chapter, which means $67 \%$ of students did not understand the material, as well as $14 \%$ of students' misconceptions on gas kinetic pressure and energy; and Jauhariyah, et al [8] found that students experienced misconceptions in all the kinetic theory subsections of gas with the highest misconception located in the kinetic energy sub-chapter caused by humanistic thinking with a percentage of misconceptions of $66.67 \%$.

Computer simulations are computer programs that try to emulate certain system models $[9,10]$. Computer simulation is a learning medium that is often used by science teachers to help students in learning where many science concepts are microscopic and macroscopic by visualizing these concepts $[9,10]$. Learning by computer simulations can change students' conceptions for the better, this is based on previous studies [10-14].

Several types of computer simulations, namely experiential and symbolic simulation (simulations that describe certain characteristics of the system, system or process through symbols), operational and conceptual simulations (simulations that have principles, concepts, and facts related to the system that is simulated when operational models), etc [15]. The use of computer simulations in learning has positive benefits for students, namely: 1) enabling students to visualize complex aspects of science because simulations can represent complex scientific processes; 2) students can manipulate a model to see how it works in various conditions; and 3) students can see the results of model changes through graphs or other representations provided by the computer simulation program used [9, 10, 16, 17].

Conceptual Change Model (CCM) is a learning model that provides opportunities for students to change existing conceptions with new conceptions in different contexts [18]. CCM was developed by Posner, et al [19] at Cornell University in the early 1980s. Posner, et al [19] developed this model based on Piaget's [20] ideas about assimilation and accommodation [18, 19]. Assimilation can be interpreted as an individual cognitive process to place or classify new events or stimuli into an existing scheme [20]. And accommodation can be interpreted as an individual process of forming a new scheme by a given stimulus and modifying an existing scheme so that it can be following a given stimulus [20].

Posner, et al [19] suggest that four conditions must be met for conceptual change to occur in the CCM, namely: (1) there must be dissatisfaction with the existing conception (dissatisfied). This is because students cannot possibly make large conceptual changes until students believe that the conceptions they believe cannot be used to solve problems; (2) the new conception must be intelligible. Students must be able to understand how experiences can be arranged with which new concepts and new concepts are sufficient to explore the possibilities that are in them; (3) the new conception must initially be plausible. Every new concept taken must appear to have the capacity to solve problems so students will decide that the new concept makes sense. Plausible can also be interpreted as a result of the consistency of the concept with other existing knowledge; (4) the new concept must suggest the possibility of a fruitful research program. Fruitful occurs when a new conception is accepted can solve problems that were not previously solved or suggest possible new directions or ideas.

In this study, the writer used CCM developed by Joseph I. Stepans [21]. CCM Stepans [21] Stephens CCM provides an opportunity for students facing confusion between new and old conceptions, so students will decide to believe in new concepts and change old concepts that are not appropriate and students will be able to apply new conceptions to different contexts [18]. Stepans [21] states that there are six sequential stages in the CCM, namely commit to a position or an outcome, expose beliefs, confront beliefs, accommodate the concept, extend the concept, and go beyond. A description of the steps of learning using CCM Stepans is shown in Table 1.

Computer simulations are used to confront beliefs phase. Because at this stage, students are expected to construct their conceptions based on their own experiences. In this study, the writer used computer simulation "PhET Interactive Simulation". Figure 1 shown the computer simulation used. 
Table 1. Description of the CCM $[18,21]$

\begin{tabular}{|c|c|c|c|}
\hline Phase & CCM & Description & Functional Dimension of the stage \\
\hline 1 & $\begin{array}{l}\text { Commit to a } \\
\text { position or an } \\
\text { outcome phase }\end{array}$ & $\begin{array}{l}\text { Students become aware of } \\
\text { their own preconceptions } \\
\text { about a concept by } \\
\text { responding to the questions, } \\
\text { or by attempting to solve the } \\
\text { problem or challenge. }\end{array}$ & $\begin{array}{l}\text { The teacher asks the student questions or presents a problem or challenge. } \\
\text { Students become aware of their own preconceptions about a concept by } \\
\text { responding to the questions, or by attempting to solve the problem or } \\
\text { challenge before any activity begins. As students formulate their answers or } \\
\text { solutions, they become familiar with their views, and may become interested } \\
\text { in knowing the answer to the question or the solution to the problem or } \\
\text { challenge. During this phase the teacher does not comment on students' } \\
\text { responses. }\end{array}$ \\
\hline 2 & $\begin{array}{l}\text { Expose beliefs } \\
\text { phase }\end{array}$ & $\begin{array}{l}\text { Students in small groups } \\
\text { share and discuss their ideas, } \\
\text { predictions and reasoning } \\
\text { with their classmates before } \\
\text { they begin to test their ideas } \\
\text { with activities. }\end{array}$ & $\begin{array}{l}\text { Students in small groups share and discuss their ideas, predictions and } \\
\text { reasoning with their classmates and a group member presents them to the } \\
\text { whole class. The teacher classifies students' responses into categories and a } \\
\text { whole-class discussion follows. This discussion gives students the } \\
\text { opportunity to change their initial beliefs and explain the reasons that led } \\
\text { them to this decision if they wish to. During this phase the teacher also does } \\
\text { not comment on students' responses, but may help students clarify their views } \\
\text { using a variety of ways. }\end{array}$ \\
\hline 3 & $\begin{array}{l}\text { Confront beliefs } \\
\text { phase }\end{array}$ & $\begin{array}{l}\text { Students confront their } \\
\text { existing ideas through } \\
\text { collaborative experiences } \\
\text { that challenge their } \\
\text { preconceptions, by working } \\
\text { with materials, collecting } \\
\text { data and consulting } \\
\text { resources. }\end{array}$ & $\begin{array}{l}\text { Students in small groups are actively engaged in learning activities, the } \\
\text { outcome of which they are required to record and interpret after discussion } \\
\text { among group members. In this phase the teacher provides technical assistance } \\
\text { to students and answer clarification questions if requested. Students in most } \\
\text { cases become dissatisfied with their existing ideas during this phase by } \\
\text { experiencing the difference between the result they were expecting and what } \\
\text { they actually see, thus giving the opportunity to the teacher to introduce and } \\
\text { develop the scientific model. }\end{array}$ \\
\hline 4 & $\begin{array}{l}\text { Accommodate } \\
\text { the concept } \\
\text { phase }\end{array}$ & $\begin{array}{l}\text { Students accommodate a } \\
\text { new view, concept or skill } \\
\text { by summarizing, discussing, } \\
\text { debating and incorporating } \\
\text { new information. }\end{array}$ & $\begin{array}{l}\text { Students whose ideas are close to scientifically acceptable ones explain their } \\
\text { views to their classmates with the aid of the teacher. After a procedure that } \\
\text { includes summarizing, discussing and debating, and incorporating new } \\
\text { information, most of the students accommodate the new concept and leave } \\
\text { their previous concepts behind. The teacher helps them draw conclusions and } \\
\text { formulate principles relating to the newly acquired information. }\end{array}$ \\
\hline 5 & $\begin{array}{l}\text { Extend the } \\
\text { concept phase }\end{array}$ & $\begin{array}{l}\text { Students apply and make } \\
\text { connections between the } \\
\text { new concept or skill and } \\
\text { other situations and ideas. }\end{array}$ & $\begin{array}{l}\text { Students apply their newly acquired knowledge and skills in different } \\
\text { situations. These situations may be presented by the teacher, or their fellow } \\
\text { classmates, or by themselves. }\end{array}$ \\
\hline 6 & $\begin{array}{l}\text { Go beyond } \\
\text { phase }\end{array}$ & $\begin{array}{l}\text { Students pose and pursue } \\
\text { new questions, ideas and } \\
\text { problems of their own. }\end{array}$ & $\begin{array}{l}\text { Students seek additional situations where acquired concepts or skills may be } \\
\text { put into practice. Students can accomplish this by delving into personal } \\
\text { experiences, questioning friends, relatives and professionals, or conducting } \\
\text { research to discover situations which can be dealt with in the same way. }\end{array}$ \\
\hline
\end{tabular}




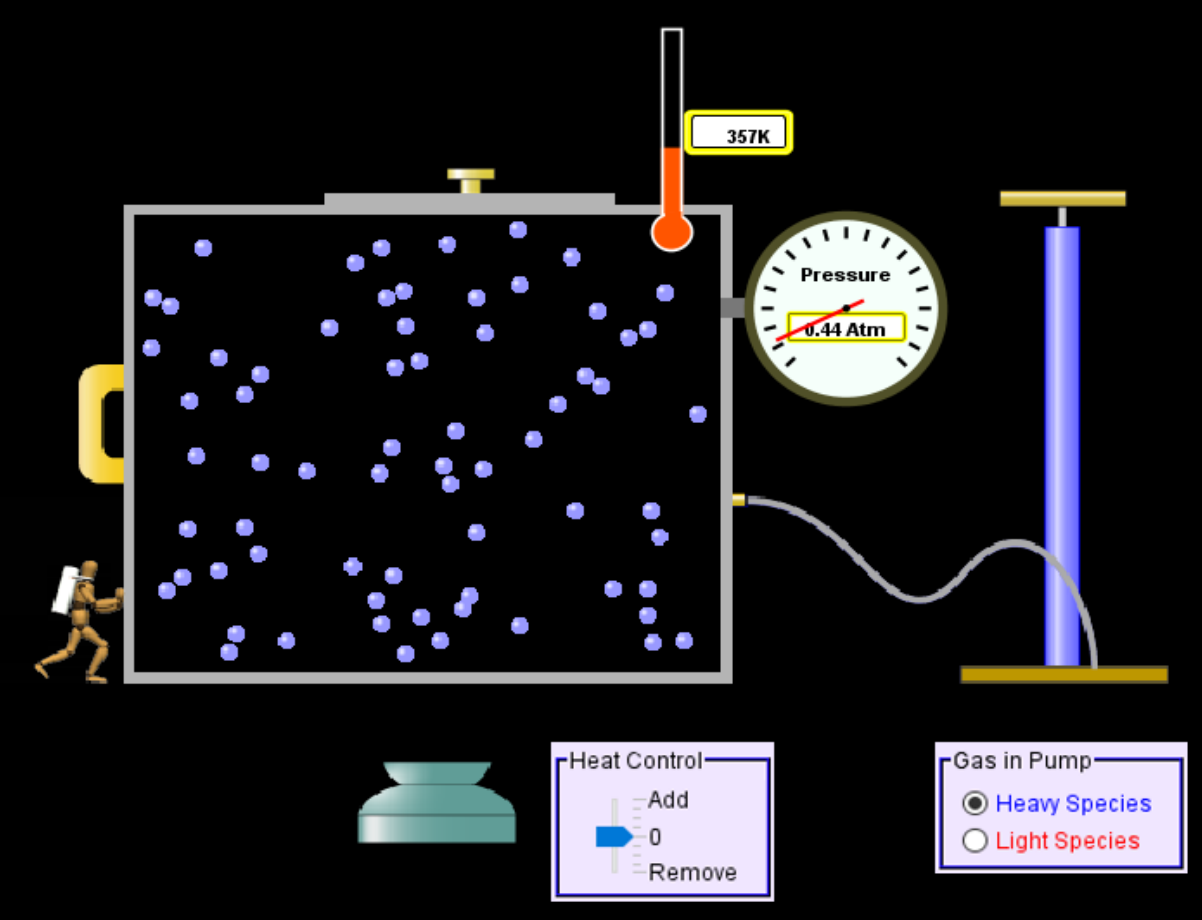

$\bigcirc$ Temperature $\bigcirc$ None

Gas in Chamber

Heavy Species $68:$

Light Species $0 \div$

Gravity

(1.

0

Tools \& Options

\section{$\ll$ Hide Tools}

$\square$ Layer tool

$\square$ Rulel

$\square$ Species information

$\square$ Stopwatch

$\square$ Energy histograms

$\square$ Center of mass markers

Advanced Options $>>$

Reset

Figure 1. PhET Interactive Simulation which is used for CS-CCM 
Based on these studies [7, 8], it can be said that students need a change of conception in the kinetic theory of gas. The computer simulations-assisted conceptual change model is the solution is chosen by the researcher to change students' conceptions. Computer simulations-assisted conceptual change model (CS-CCM) is a learning model that combines conceptual change models and computer simulations. CS-CCM is a learning model that provides opportunities for students to change existing conceptions with new conceptions in different contexts were in the process of changing the conceptions of students aided by learning media in the form of computer simulations.

Based on the above description, this study aims to analyze the conceptual change students on the kinetic theory of gases after learning with the computer simulation-assisted conceptual change model.

\section{Materials and Methods}

\subsection{Research Design}

In this study, the writer used a pre-experimental. With pre-experimental designs, the researcher studies a single group and provides an intervention during the experiment. This design does not have a control group to compare with the experimental group [22]. The type of pre-experimental design used is a one-group pretest-posttest design. This design includes a pretest measure followed by a treatment and a posttest for a single group. One-group pretest-posttest design is shown in Figure 2.

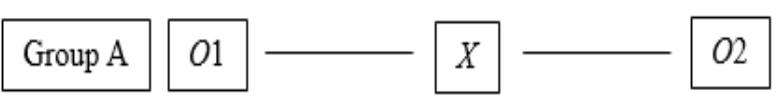

Figure 2. One-Group Pretest-Posttest Design

Based on Figure 1, O represents measurement recorded on an instrument, $\mathrm{X}$ represents an exposure of a group to an experimental variable or event, the effects of which are to be measured. The left-to-right dimension indicates the temporal order of procedures in the experiment [22].

\subsection{Participants}

27 participants with an average age of 17 years who came from one of high school in Belitung. The students who participated in this study were mostly from the Malay tribe and some Chinese Hokkien and Hakka descendants. Belitung is one of the islands in Indonesia located off the east coast of Sumatra and flanked by the Gaspar Strait and the Karimata Strait and it is located $415 \mathrm{~km}$ from DKI Jakarta, Indonesia. Figure 3 shows a map distance DKI Jakarta - Tanjung Pandan, Belitung which is where the research was conducted.

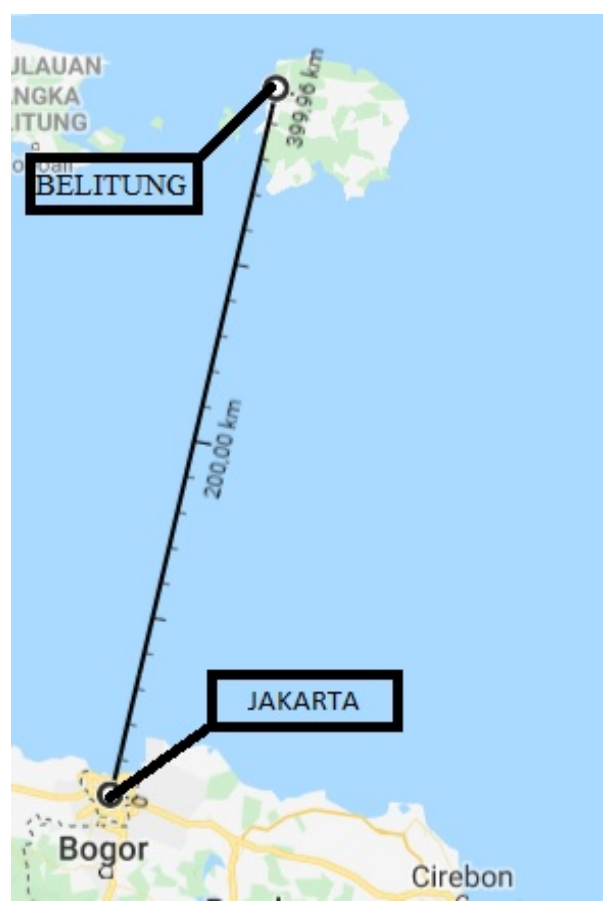

Figure 3. Map of the DKI Jakarta-Tanjungpandan, Belitung[24]

\subsection{Instrument}

Four-tier test-kinetic theory of gases (FT-KTG) was used as an instrument in this study. FT-KTG is a diagnostic test kinetic theory of gases consists of four levels of questions. Tier- 1 contains ordinary multiple-choice questions, tier-2 contains questions of confidence in the answers chosen in tier-1, tier- 3 contains a choice of reasons why to choose answers in tier- 1 , and tier- 4 contains questions of confidence in the answers chosen in tier-3.

The FT-KTG consists of 11 questions covering 10 concept which includes the kinetic theory of gases. The concepts included in the FT-KTG are the microscopic and macroscopic properties of the gas (question number 1), the ideal gas assumption (number 2), Boyle's law (question number 3), Gay Lussac's law (questions number 4 and 5), Charles law (question number 6), the ideal gas equation (problem number 7), ideal gas pressure speed (problem number 10), and the energy equipartition theorem (question number 11).

The FT-KTG instrument used to retrieve data has been validated by experts. The average validity score is 0.96 , the value obtained $\geqslant 0.90$ [32], so it can be concluded that the FT-KTG diagnostic test consists of 11 valid questions according to experts and is suitable for use as instruments in this study. And FT-KTG reliability was calculated using Cronbach's alpha, FT-KTG reliability, as a whole was 0.87 , the value obtained was $0.70<\mathrm{r} \_11 \leqslant$ 0.90 [29], so it can be concluded that the FT-KTG has a high level of confidence and can provide permanent results.

One of the questions from the FT-KTG is shown in Figure 4 below. 


\begin{tabular}{|c|c|}
\hline & $\begin{array}{l}\text { 6. There is a pan filled with hot water and a bottle filled with air with the mouth of the bottle closed tightly by a balloon,as } \\
\text { in the following picture. } \\
\text { HOT } \\
\text { WATER }\end{array}$ \\
\hline Tier-1 & $\begin{array}{l}\text { Note: the orange object on top of the bottle is a balloon. } \\
\text { The bottle is then dipped in hot water,what will happen to the balloon in the mouth of the bottle? } \\
\text { A.The balloon will enter the bottle. } \\
\text { B.The balloon will deflate. } \\
\text { C.The balloon will deflate and enter the bottle. } \\
\text { D.The balloon will enter the bottle and expand. } \\
\text { E.The balloon will inflate. }\end{array}$ \\
\hline Tier-2 & $\begin{array}{l}\text { Are you sure about your answer? } \\
\text { A.Sure } \\
\text { B.Not Sure }\end{array}$ \\
\hline Tier-3 & $\begin{array}{l}\text { What are your reasons for answering the questions above? } \\
\text { A.The air temperature in the bottle increases so that the air pressure becomes large and the volume of air expands causing } \\
\text { air from the bottle to flow into the balloon. } \\
\text { B.The air molecules which were initially united when heated became spread in all directions to fill the empty spots. } \\
\text { C.Air pressure decreases due to rising air temperatures so that air from outside flows into the bottle causing balloons to } \\
\text { enter the bottle. } \\
\text { D.The water in the pan evaporates and goes into the balloon. } \\
\text { E.Hot water causes the air in the bottle to disappear. }\end{array}$ \\
\hline Tier-4 & $\begin{array}{l}\text { Are you sure about your answer? } \\
\text { A.Sure } \\
\text { B.Not Sure }\end{array}$ \\
\hline
\end{tabular}

Figure 4. Example questions about the four tiers test-kinetic theory of gases

\begin{tabular}{|c|l|c|}
\hline \multicolumn{2}{|c|}{$1^{\text {st Meeting }}$} & Tearning \\
Structure & \multicolumn{1}{|c|}{ Learning Activities } \\
\hline $\begin{array}{c}\text { Core } \\
\text { Activities }\end{array}$ & $\begin{array}{l}\text { Phase 3: Confront beliefs phase (explore computer simulation } \\
\text { phase) }\end{array}$ & 23. The teacher directs students to begin the exploration of PhET \\
siulations for Tasks I, I, and III. & $\begin{array}{l}\text { 24. Each group begins to explore the PhET simulation. } \\
\text { 25. After exploring the PhET simulation, student conduct a } \\
\text { discussion related to the results the results obtained from the } \\
\text { simulation. }\end{array}$ & \\
\hline
\end{tabular}

Figure 5. Example of learning scenario

\subsection{Data Collection}

The process of taking data occurs during the learning process. Learning by CS-CCM was conducted in two meetings and witnessed by three observers. At the first meeting, students learn about the ideal gas and the laws underlying the ideal gas equation. And, on the second meeting, students learn about the kinetic theory of gas, such as gas pressure in a closed space, the effective speed of gas, etc. Before starting to learn to use CS-CCM, students' initial conceptions are measured using FT-KTG, the data obtained from this process is called pre-test result data. Then, after the pre-test is done, learning is carried out by the learning implementation plan. Examples of learning implementation plans can be seen in Figure 5 .
Based on Figure 5, it can be seen that computer exploration activities are carried out at the core activities. The core activities at the first meeting were held for 135 minutes. During the core activities, students carry out the six stages of CS-CCM, namely: 1) Commit to a position or outcome phase; 2) Exposed belief phase; 3) Confront belief phase (explore computer simulation phase); 4) Accommodation the concept phase; 5) Extend the concept phase; 6) Go beyond the phase.

When learning, students do several activities, namely answering student worksheets, exploring PhET simulations and presenting their work. These student activities can be seen based on Figures 6, 7, 8 and 9 below. 


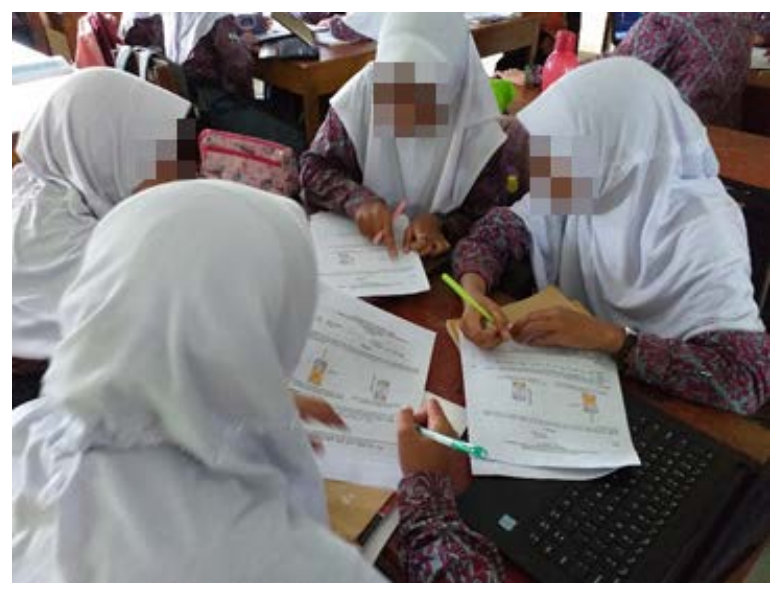

Figure 6. Students are discussing to answer worksheets

student worksheet in the form of PDEODE*E. The PDEODE*E is a worksheet involving seven stages, which are Predict (P), Discuss (D), Explain (E), Observe (O), Discuss (D), Explore (E*) and Explain (E) [12,31].

Figure 7 shows one of the students' answers on the PDEODE * E worksheet about the effective speed of gas in confined spaces. Figure 7 a shows students' answers that "if the box in the PhET application is a closed container and a heavy type molecule is a type of gas in container 1 and a light type molecule is a type of gas in container 2, then the average velocity of light type gas molecules is greater than the molecules heavy type gas ". And, Figure 7b shows students' answers that "if the temperature of the closed container (the box in the PhET application) is raised and there are molecules in it, the average speed of the gas molecule will increase".

Figure 6 shows students who are discussing to answer a

a. Asumsikan kotak pada aplikasi PhET adalah bejana tertutup dan molekul jenis berat adalah jenis gas pada bejana I serta molekul jenis ringan adalah jenis gas pada bejana II. Bagaimana kecepatan rata-rata molekul gas jenis ringan dan jenis berat?

Kecepatan rata-rata molekol gas jenis rimgan lebih besar daripada molekul
gas jenis berat.

b. Asumsikan kotak pada aplikasi PhET adalah bejana tertutup. Masukkan molekul ke dalam kotak dan naikkan suhu kotak sehingga suhu molekul juga meningkat. Bagaimana kecepatan rata-rata molekul gas ketika suhu gas meningkat? Kecepatan rata-rata-nya juga akan meningkat, ketika suhu gas ayja
meningkat.

a. Assume the box in the $\mathrm{PhET}$ application is a closed container and the heavy type molecule is the type of gas in the container I and light type molecule is the type of gas in container II. How are the average velocity of light and heavy type gas molecules? The average velocity of light type gas molecules is greater than heavy type gas molecules.

(n)

b. Assume the box in the PhET application is a closed container. Put the molecule in the box and increase the temperature of the box so that the temperature of the molecule also rises. How is the average velocity of the gas molecule when the temperature of the gas rises?

The average velocity will also increase, as the gas temperature increases.

(B)

Figure 7. Example student answers on the PDEODE*E worksheet ((A) students' original answers and (B) translated in english) 


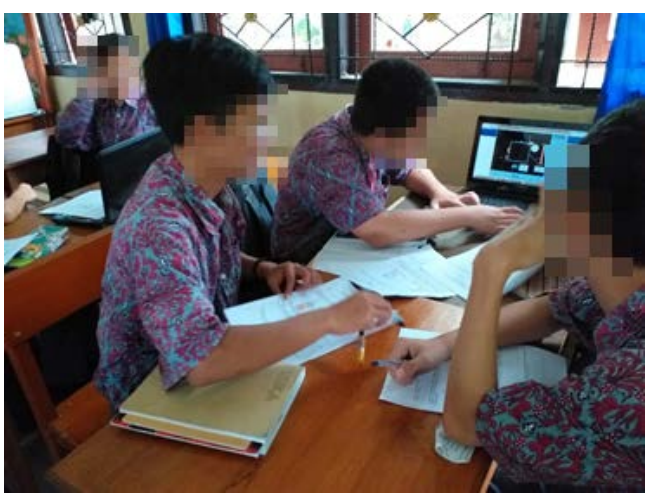

Figure 8. Students explore the PhET simulation

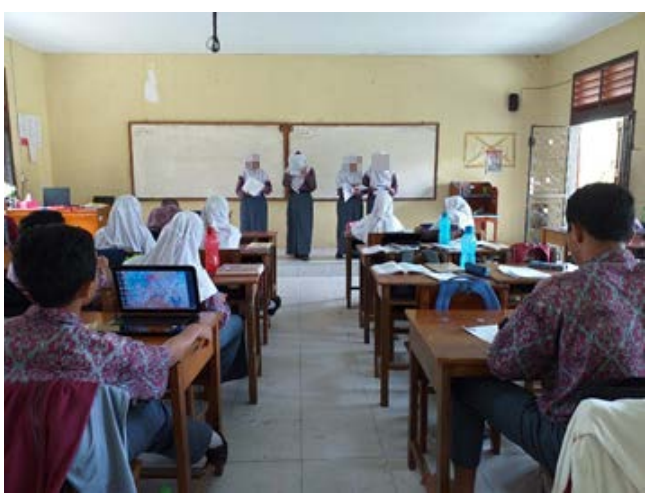

Figure 9. Students present the results of group activities
The students' answers in Figure 7 were obtained after computer exploration as in Figure 8. Figure 8 shows a group of students who were exploring PhET simulations.

Figure 9 shows a group of students who presented their work during the lesson. Students in Figure 9 in addition to making presentations, the students also held discussions with other groups related to their work.

After learning with CS-CCM, the test is carried out using FT-KTG to get a picture of changes in students' conceptions, the data obtained from this process is called post-test results data.

\subsection{Data Analysis}

Data were analyzed after participants filled out the pre-test and post-test. The results of the pre-test and post-test were categorized into five categories consisting of; sound understanding (SU), partial understanding (PU), misconception (MC), no understanding (NU), and not being encoded (UC) [6]. The categories are shown in Table 2.

Conceptual change students' on the kinetic theory of gas after the application of CS-CCM are based on the students' conception profiles obtained from the pre-test and post-test results. The categories and analysis of conception change are based on Table 3 which was adapted from previous studies [5, 6, 23].

Table 2. Understanding level Category

\begin{tabular}{|c|c|c|c|c|}
\hline Tier 1 & Tier 2 & Tier 3 & Tier 4 & Category \\
\hline True & Sure & True & Sure & Sound Understanding (SU) \\
\hline True & Sure & True & Unsure & \multirow{7}{*}{ Partial Understanding (PU) } \\
\hline True & Unsure & True & Sure & \\
\hline True & Unsure & True & Unsure & \\
\hline True & Sure & False & Sure & \\
\hline True & Sure & False & Unsure & \\
\hline True & Unsure & False & Sure & \\
\hline True & Unsure & False & Unsure & \\
\hline False & Sure & False & Sure & Misconception (MC) \\
\hline False & Sure & False & Unsure & \multirow{3}{*}{ No Understanding (NU) } \\
\hline False & Unsure & False & Sure & \\
\hline False & Unsure & False & Unsure & \\
\hline \multicolumn{4}{|c|}{11 are not filled) } & Not Being Encoded (UC) \\
\hline
\end{tabular}


Table 3. Categories and Analysis of Conceptual

\begin{tabular}{|c|c|c|c|c|}
\hline Pre-Test & Post-Test & Change Type & Change Category & Interpretation \\
\hline PU & SU & $\mathrm{Ri}$ & \multirow{7}{*}{ Acceptable (A) } & \multirow{7}{*}{ Satisfactory (S) } \\
\hline MC & PU & \multirow{2}{*}{ Rv } & & \\
\hline MC & SU & & & \\
\hline NU & PU & \multirow{4}{*}{ Co } & & \\
\hline NU & SU & & & \\
\hline UC & PU & & & \\
\hline UC & SU & & & \\
\hline SU & PU & \multirow{13}{*}{$\mathrm{Di}$} & \multirow{13}{*}{ Not Acceptable (NA) } & \multirow{13}{*}{ Dissatisfactory (Ds) } \\
\hline SU & MC & & & \\
\hline SU & $\mathrm{NU}$ & & & \\
\hline SU & UC & & & \\
\hline $\mathrm{PU}$ & MC & & & \\
\hline $\mathrm{PU}$ & NU & & & \\
\hline $\mathrm{PU}$ & UC & & & \\
\hline MC & $\mathrm{NU}$ & & & \\
\hline MC & UC & & & \\
\hline NU & MC & & & \\
\hline $\mathrm{NU}$ & UC & & & \\
\hline UC & MC & & & \\
\hline UC & NU & & & \\
\hline PU & PU & \multirow{2}{*}{ Sc } & \multirow{5}{*}{ No Change (NC) } & \multirow{2}{*}{ Satisfactory (S) } \\
\hline SU & SU & & & \\
\hline MC & MC & \multirow{3}{*}{ St } & & \multirow{3}{*}{ Dissatisfactory (Ds) } \\
\hline NU & $\mathrm{NU}$ & & & \\
\hline UC & UC & & & \\
\hline
\end{tabular}

Based on Table 3, in the acceptable category, the direction of students' conception change can be divided into three types, namely: 1) Reinterpretation (Ri), which is a change in conception that is indicated by the fulfillment of the conception where the initial conception that is in accordance with the concept of the scientist is combined with a new concept so that students who initially understand part of the concept of understanding the concept; 2) Revision (Rv), namely a change in conception that is indicated by the rearrangement of the wrong conception into a conception that is in accordance with the concept of the scientist so that students who initially misconceptions become aware of the concept or understand some of the concepts; and 3) Construction
(Co), which is a change in conception that is indicated by the formation of a series of new concepts so that students who initially did not understand the concept or concept cannot be coded into understanding the concept or understanding some of the concepts.

Changes in the conception are categorized as not acceptable if the students' conception changes in an unexpected direction after the treatment is given. The type of conception change in this category is called Disorientation (Di). Disorientation (Di) is a change in the concept indicated by a decrease in the conception of students, namely students who already understand the concept or understand some concepts into misconceptions, do not understand the concept or concept cannot be coded. 
And the change in the conception is categorized as no change if the conception of students does not experience a change in conception after treatment is given. In this category, there are two types of consistency of students' conceptions, namely: 1) Scientific conception from beginning (Sc), students whose conceptions persist in the expected conceptions, namely students who are consistent in the concept of understanding concepts or understanding some concepts; and 2) Static (St), students whose conceptions persist in unexpected conceptions, namely students who are consistent in the category of misconception, do not understand concepts, or conceptions that cannot be coded.

The percentage of conceptual change students' can be calculated using (1) below.

$$
\% P_{p e r} K=\frac{J P}{J T} \times 100 \%
$$

Based on (1), $\% P_{p e r} K$ represents the percentage of conceptual change students', JP represents the number of students experiencing changes according to a category, and JT represents the total number of students.

\section{Result and Discussion}

Conceptual change students' after learning can be known by analyzing the students' conception profiles from the results of pre-test and post-test students and categorizing the six types of changes, namely reinterpretation (Ri), revision (Rv), construction (Co), disorientation (Di), scientific conception from beginning (Sc), and static (St). Percentage conceptual change students' after learning is shown in Table 4 below.

Table 4. Percentage Students' Conceptual Change

\begin{tabular}{|c|c|c|c|c|c|c|}
\hline \multirow{2}{*}{ Question } & \multicolumn{6}{|c|}{ Conceptual Change Type (\%) } \\
\cline { 2 - 7 } & Ri & Rv & Co & Di & Sc & St \\
\hline 1. & 52 & 22 & 0 & 0 & 22 & 4 \\
\hline 2. & 30 & 19 & 22 & 4 & 26 & 0 \\
\hline 3. & 26 & 7 & 7 & 19 & 30 & 11 \\
\hline 4. & 30 & 7 & 15 & 19 & 26 & 4 \\
\hline 5. & 26 & 26 & 4 & 15 & 26 & 4 \\
\hline 6. & 15 & 11 & 11 & 4 & 59 & 0 \\
\hline 7. & 22 & 11 & 33 & 4 & 22 & 7 \\
\hline 8. & 33 & 19 & 7 & 0 & 41 & 0 \\
\hline 9. & 15 & 26 & 30 & 0 & 26 & 4 \\
\hline 10. & 19 & 11 & 26 & 15 & 11 & 19 \\
\hline 11. & 33 & 4 & 11 & 22 & 26 & 4 \\
\hline Average* & 27 & 15 & 15 & 9 & 29 & 5 \\
\hline
\end{tabular}

*Note: average percentage conceptual change students'

Based on Table 4, it can be seen that the largest average percentage of students' conceptual changes are in the reinterpretation category of $27 \%$ with the largest conception change located in item number 1 which discusses the microscopic and macroscopic properties of gases. And for the type of conception change with the revision category, the average percentage of students' conceptual change is $15 \%$. And, for the type of conception change based on the construction category, the average percentage of students' conceptual change is $15 \%$. Reinterpretation, revision, and construction are changes in conception that are acceptable and fall into the satisfactory category.

Meanwhile, for the type of conception change with the disorientation category, the average percentage of students' conceptual changes was $9 \%$. This category is categorized as dissatisfactory and concept change is not acceptable. Students who have not experienced a change of conception are included in the scientific conception category from the start and are static. As many as $29 \%$ of students whose type of conceptual change was included in the category of scientific conception from the beginning, this type of conceptual change was included in the satisfactory category. And for 5\% of students whose type of conceptual change is in the static category, this type of conceptual change is in the dissatisfactory category.

From the results of data processing, it can be seen that changes in conception whose results can be accepted and fall into the satisfying category are greater than those that are unacceptable and unsatisfactory.

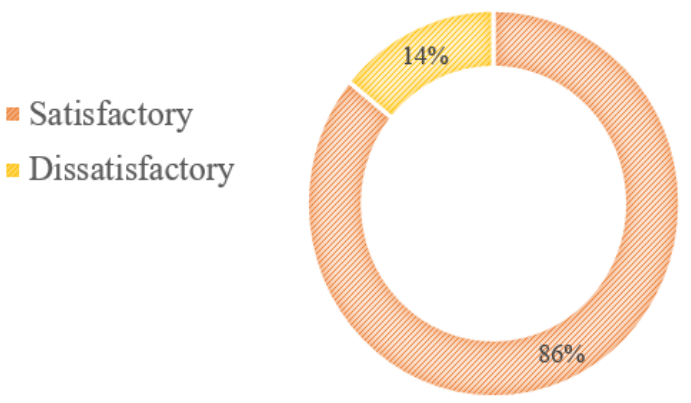

Figure 10. Percentage Students' Conceptual Change with Satisfactory Category

Based on Figure 10, 86\% of students whose conceptual changes are in the "satisfying" category and only $14 \%$ of students whose conceptual changes are in the "unsatisfactory" category. Thus, it can be said that after learning with CS-CCM, the average student experiences a conceptual change in the expected direction.

And based on Figure 11, that as many as $57.2 \%$ of students whose conceptual change is acceptable and only $9 \%$ of students whose conceptual change is not acceptable. Also, 34\% of students did not experience a change in conception, with $29 \%$ of students not experiencing a change in conception, but included in the satisfactory category and only $5 \%$ of students who did not experience 
a change in conception, but included in the dissatisfactory category.

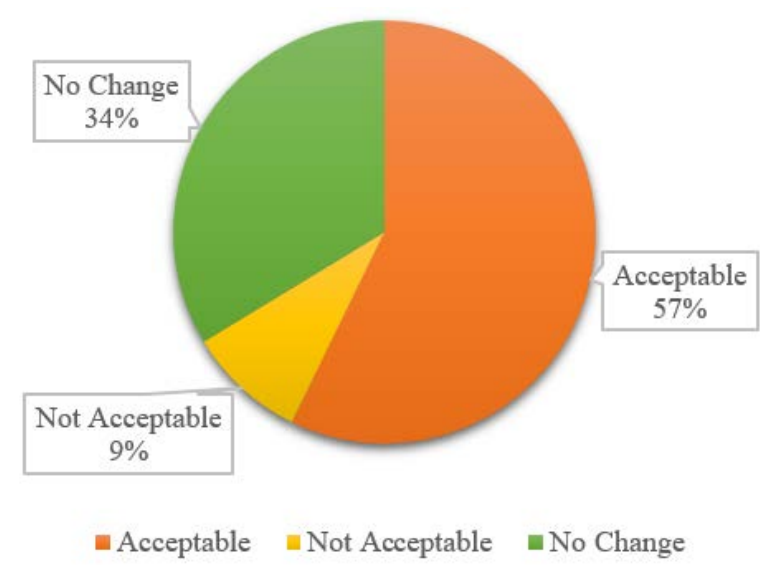

Figure 11. Percentage Students' Conceptual Change with Acceptable, Not Acceptable, and No Change Category

From further analysis, changes in students' conceptions can be seen in the distribution of students in question number 10 which can be seen in Table 5 below.

Table 5. Distribution of changes in the conception of student in question number 10

\begin{tabular}{|c|c|l|}
\hline No. & Change Type & \multicolumn{1}{|c|}{ Student Code } \\
\hline 1. & Di & E22 \\
\hline 2. & Sc & E11, E15, E25 \\
\hline 3. & $\mathrm{Ri}$ & E4, E7, E10, E14, E23 \\
\hline 4. & St & E1, E9, E12 \\
\hline 5. & $\mathrm{Rv}$ & E13, E18, E20 \\
\hline 6. & St & E8, E24 \\
\hline 7. & Co & E16, E26 \\
\hline 8. & Co & E5, E6, E17, E19, E21 \\
\hline 9. & Di & E2, E3, E27 \\
\hline
\end{tabular}

Based on Table 5, students with code E16 answer question number 10 about the average effective speed of the ideal gas with "the average effective speed of gas in cylinder A is smaller than the average effective speed of gas in cylinder $\mathrm{C}$ " for the reason given "because the molar mass of gas is proportional inversely with the average effective speed of gas with the same gas temperature.” In problem number 10 it is known that cylinder $\mathrm{A}$ has a molar mass and gas temperature that is different from cylinder $\mathrm{C}$ so that E16 is diagnosed by not understanding the concept.

When carrying out PhET simulation exploration activities E16 students find that "the average velocity of the gas increases when the temperature increases and the average speed of light type gas molecules are greater than heavy type gas molecules." After exploration, E16 students deepen the material and based on the handbook
E16 students find that "the average effective speed of a gas is inversely proportional to the root of its relative molecular mass." Based on these activities, E16 students conclude that "the effective speed of a gas depends on the temperature and molar mass of the gas, the effective speed of the gas is directly proportional to the temperature of the gas and the effective speed of the gas is inversely proportional to the root of the molar mass of the gas. After learning E16, using the concept to answer the post-test questions so that E16 students are then diagnosed by understanding the concept.

\section{Conclusions}

Based on data analysis, it can be seen that students have their conceptions before learning is carried out following statements from previous studies [7,8]. This student's conception can be changed in the desired direction using appropriate treatment. The treatment used by the researchers in this study was a computer simulation-assisted conceptual change model. By using this treatment, students can change their conceptions for the better. This is indicated by the results that $86 \%$ of students experienced a satisfactory conceptual change and $57 \%$ of students experienced an acceptable conceptual change. Where the percentage of students' conceptual changes that can be accepted consists of; $27 \%$ of students who experienced conceptual changes in the reinterpretation category and $15 \%$ of students each experienced a conceptual change in the revision and construction categories.

The results of this study also found students who experienced a conceptual change in an unsatisfactory direction, amounting to $14 \%$. These results indicate that there are still students whose conceptions of students are still resistant and difficult to remove even after treatment. The results obtained are in line with the results of previous studies [10].

Student conceptual changes occur during the learning process. Special attention in each step of learning is needed so that students' conceptions can be transformed into concepts that are believed by scientists. Based on the learning process that takes place during the study, the researcher recommends paying more attention to commit to a position or an outcome and accommodate the concept phase. In commit to a position or an outcome phase, it is necessary to show phenomena that students can see in their daily lives so that students become more aware of their initial conceptions before learning is given. This is because the student's initial conception is a guide for the teacher to provide direction for conceptual changes that are appropriate for students. And, to accommodate the concept phase, direction and teacher assistance is needed to infer the concepts learned previously. This is very necessary because the summary of concepts obtained by 
students at this stage must be by concepts that are trusted by scientists. So, students do not experience misconceptions about the concept.

Finally, researchers suggest using computer simulations-assisted conceptual change models to change students' concepts. Because the computer simulations-assisted conceptual change model effectively changes students' conceptions for the better.

\section{Acknowledgements}

The author would like to thank the Ministry of Higher Education, Research and Technology, The republic of Indonesia, which has funded this through the publication of the research (Penelitian Strategi Nasional Institusi research-grand, Hibah Tesis Pascasarjana and Hibah Terapan).

\section{REFERENCES}

[1] M. Limón, L. Mason, Recosindering Conceptual Change: Issues in Theory and Practice, Kluwer Academic Publisher, New York, Boston, Dordrecht, London, Moscow, 2002.

[2] R. T. White, Commentary Conceptual and Conceptual Change, Learning and Instruction, 117-121, 1994.

[3] K. A. Topalsan, H. Bayram, Eliminate with Created Argument Environment after Evaluated and Categorized Misconceptions in an Ontological Sense, Eurasian Journal of Educational Research, 69, 1-19, 2017.

[4] B.C. Madu, E. Orji. Effects of Cognitive Conflict Instructional Strategy on Students' Conceptual Change in Temperature and Heat, SAGE Open, 1-8, 2015.

[5] A. M. Rusanen, O. Lappi, What, When and How do the Models of Conceptual Change Explain?, Proceedings of the Annual Meeting of the Cognitive Science Society, 35, 3331-3336, 2013.

[6] A. Samsudin, A. Suhandi, D. Rusdiana, I. Kaniawati, B. Costu, Investigating the effectiveness of an active learning based-interactive conceptual instruction (ALBICI) on electric field concept, sia-Pacific Forum on Science Learning and Teaching, 17, 2016.

[7] T. Nurhuda, D. Rusdiana, W. Setiawan, Analyzing Students' Level of Understanding on Kinetic Theory of Gases, Journal of Physics: Conference Series, 812, 2017.

[8] M. N. Jauhariyah, N. Suprapto, Suliyanah, S. Admoko, Setyarsih, Z. Harizah, I. Zulfa, The Students' misconceptions profile on chapter gas kinetic theory, Journal of Physics: Conference Series, 997, 1-13, 2018.

[9] S. Khan, New Pedagogies on Teaching Science with Computer Simulations, Journal of Science Education and Technology, 20, 215-232, 2010.

[10] U. Ramnarain, S. Moosa, The Use of Simulations in Correcting Electricity Misconceptuions of Grade 10 South
African Physical Science Learners, International Journal of Innovation in Science and Mathematics Education, 25(5),1-20, 2017, 25, 1-20, 2017.

[11] R. L. Bell, K. C. Trundle, The Use of a Computer Simulation to Promote Scientific Conceptions of Moon Phases, Journal of Research in Science Teaching, 45, 3, 346-372, 2008.

[12] N. J. Fratiwi, A. Samsudin, B. Costu, Enhacing K-10 Students' Conceptions Through Computer Simulation-Aided PDEODE*E (CS-PDEODE*E) On Newton's Laws, Jurnal Pendidikan IPA Indonesia, 214-223, 2007.

[13] K. C. Trundle, R. L. Bell, The Use of a Computer Simulation to promote conceptual change: A quasi-experimental study, Computers \& Education, 54, 1078-1088, 2010.

[14] T. Hirashima, T. Shinohara, A. Yamada, Y. Hayashi, T. Horiguchi, Effects of Error-Based Simulation as a Counterexample for Correcting MIF Misconception, AIED 2017, LNAI 10331, 90-101, 2017.

[15] M. Jancheski, The Importance of Animations and Simulation in the Process of E-learning, 8th Conference on Informatics and Information Technology with International Participation, 177-181, 2011.

[16] N. Rutten, W. R. Joolingen, J. T. Veen, The Learning Effects of Computer Simulations in Science Education, Computers \& Education, 58, 136-153, 2012.

[17] M. Windschitl, T. Andre, Using Computer Simulations to Enhance Conceptual Change: The Roles of Constructivist Instruction and Student Epistemological Beliefs, Journal of Research in Science Teaching, 35, 145-160, 1998.

[18] A. Kapartzianis, J. Kriek, Conceptual Change Activities Alleviating Misconceptions About Electric Circuits, Journal of Baltic Science Education, Vol. 13, No.3, 2014, 13, 298-315, 2014.

[19] G. J. Posner, K. A. Strike, P. W. Hewson, W. A. Gertzog, Accomodation of a Scientific Conception: Toward a Theory of Conceptual Change, John Wiley \& Sons, Inc., 66, 211-227, 1982.

[20] J. Piaget, The Psychology of Intelligence, Taylor \& Francis e-Library, 2005.

[21] J. Stepans, Targeting Students' Science Misconceptions, Showboard, Inc, Florida, 2006.

[22] J. W. Creswell, Research Design: Qualitative, Quantitative, and Mixed Methods Approaches, Sage Publications, California.

[23] F. Ulya, A. Suhandi, A. Samsudin, Achievement of Conceived Level of Change of High School Student as Effect of Video Supported Conceptual Change Text (VSCCText) Teaching Remedial Concept Boil, International Conference on Mathematics and Science Education, 168-172, 2018.

[24] Google Inc, Google Maps, Online available from https://www.google.com/maps/dir/Jakarta,+Daerah+Khusu s+Ibukota+Jakarta/Tanjung+Pandan,+Tj.+Pandan,+Kabup aten+Belitung,+Kepulauan+Bangka+Belitung/

[25] P. A. Tipler, PHYSICS for Scientist and Engineers, World Publisher, Inc, 1991. 
[26] B. Costu, A. Ayas, M. Niaz, M. Calik, Facilitating Conceptual Change in Students' Understanding of Boiling Concept, Journal Science Education and Technology, 524-536, 2007.

[27] D. F. Polit, C. T. Beck, The Content Validity Index: Are You Sure You Know What's Being Reported? Critique and Recommendation. Research in Nursing \& Health, 489-497, 2006.

[28] J. R. Read, Children's Misconceptions and Conceptual Change in Science Education, Online available from http://acell.chem.usyd.edu.au/Conceptual-Change.cfm

[29] H. Taherdoost, Validity and Reliability of the Research Instrument; How to Test the Validation of a Questionnaire/Survey in a Research, International Journal of Academic Research in Management, 5, 28-36, 2016.

[30] A. Suhandi, N. Hermita, A. Samsudin, B. Maftuh, B. Costu, Effectiveness of Visual Multimedia Supported Conceptual Change Texts on Overcoming Students' Misconception About Boiling Concept, TOJET: The Turkish Online Journal of Educational Technology, 1012-1020s, 2017.

[31] A. Samsudin, N. J. Fartiwi, I. Kaniawati, E. Suhendi, N. Hermita, A. Suhandi, B. Costu, J. Akbardin, S. Supriyatman, Alleviating Students' Misconceptions About Newton's First Law Through Comparing Pdeode*e Tasks and Poe Tasks: Which is More Effective? The Turkish Online Journal of Educational Technology, Special Issue for INTE 2017, 2017.

[32] V. P. Tilden, C. A. Nelson, B. A. May, Use of Qualitative Methods to Enhance Content Validity, Nurising Research, 1990 